\title{
Mineral Salt Medium for the Growth of Botrytis cinerea in vitro
}

\author{
Noboru Shirane* and Takayuki Hatta*
}

\begin{abstract}
A mineral salt (MS) medium suitable for culturing Botrytis cinerea in vitro is described. The MS medium contains trisodium citrate, $\mathrm{MnSO}_{4}, \mathrm{MgSO}_{4}, \mathrm{ZnSO}_{4}, \mathrm{NH}_{4} \mathrm{NO}_{3}, \mathrm{KH}_{2} \mathrm{PO}_{4}, \mathrm{CaCl}_{2}$, $\mathrm{Na}_{2} \mathrm{MoO}_{4}$, vitamin A palmitate, and sucrose. B. cinerea grew vigorously and sporulated numerous conidia in MS agar-medium similarly to those in potato sucrose (PS) agarmedium. The growth was poor if any one of the components in MS medium was omitted. Especially when $\mathrm{MgSO}_{4}, \mathrm{NH}_{4} \mathrm{NO}_{3}, \mathrm{KH}_{2} \mathrm{PO}_{4}$ or sucrose was omitted, almost no growth of the mycelium was resulted, suggesting these components appear to be essential. When cucumber leaves were inoculated with the spores suspended in the MS medium the symptom of gray mold rot appeared, but the symptom did not appear when inoculation was made with spores suspended in distilled water. However, the omission of $\mathrm{NH}_{4} \mathrm{NO}_{3}, \mathrm{KH}_{2} \mathrm{PO}_{4}$ or sucrose from the MS medium led to remarkable decrease of infection. A large number of protoplasts with little cell wall debris were isolated by the standard isolation technique ${ }^{6)}$ from $40 \mathrm{hr}$-old mycelium which were cultured in the MS medium. These protoplasts reverted to mycelium at $30-60 \%$ after they were incubated in the reversion medium.
\end{abstract}

(Received November 5, 1986)

Key words : Botrytis cinerea, mineral salt medium, protoplast.

\section{Introduction}

Botrytis cinerea has been usually cultured in vitro on potato-sucrose, potato-dextrose or other media. But the nutrients containing in these media were not defined in any detail, therefore the quality and quantity of the nutrients appear not to be constant from laboratory to laboratory. We think it necessary to establish the chemically defined medium for the biochemical studies on $B$. cinerea such as infection mechanism, mode of action of fungicide, or mechanism of fungicide resistance. MS medium originally came from Murashige and Skoog medium ${ }^{5)}$ in which, we noticed, B. cinerea grew and sporulated. The aim of the investigation in this report is to determine the components in MS medium necessary for the growth, sporulation and infection of $B$. cinerea.

\section{Materials and Methods}

Preparation of B. cinerea spores as starting material. A single spore (isolate $\mathrm{S}-\mathrm{v}-5$ ) of $B$. cinerea was grown on potato-sucrose (PS: decoction of $200 \mathrm{~g}$ potato and $20 \mathrm{~g}$ sucrose in 1 liter of distilled water) agar-medium for 3 days at $22 \mathrm{C}$. The

* Aburahi Laboratories, Shionogi Research Laboratories, Shionogi \& Co., Ltd., Koka-cho, Shiga 52034, Japan 塩野義製薬㑣油日ラボラトリーズ 
culture was illuminated by near-ultraviolet light (FL 20S, BL-B: Matsushita Co., Ltd.) for 2 days and then sporulated under dark condition for 2 days. The spores formed were washed three times with distilled water and stocked at $-80 \mathrm{C}$.

Measurement of fungal growth in vitro. The spores stocked were suspended in $20 \mathrm{ml}$ of various media to be tested $\left(2 \times 10^{4}\right.$ spores $\left./ \mathrm{ml}\right)$ in Petri dish and incubated for $65 \mathrm{hr}$ at $22 \mathrm{C}$ under the dark. Three replicates were carried out for each medium. The mycelium grown in the Petri dishes was collected and centrifuged at $2,200 \times g$ for $5 \mathrm{~min}$ and fresh weight of the precipitate was measured.

Sporulation and spore germination. A droplet $(5 \mu 1)$ of distilled water containing $5 \times 10^{4}$ spores was placed on each MS agar (0.5\% agarose A45: Nakarai chemicals, Ltd.) -medium in Petri dish and incubated at $22 \mathrm{C}$ under the dark for 4 days. The condition for the sporulation was as described above. The number of spores developed on the agar-medium was counted using a Burker Turk hemacytometer. Germination of spores was observed in PS medium after incubation for $15 \mathrm{hr}$.

Inoculation and infection. Leaves of cucumber (Cucumis sativus L.) were harvested from 2 week-old plants and punched into disks (20 $\mathrm{mm}$ in diameter). These leaf disks were plated on $0.35 \%$ agar in Petri dish. Thirty leaf disks, each with one inoculation, were provided for each test medium. Droplets $(10 \mu 1)$ of test medium containing $2 \times 10^{2}$ spores were placed on the under leaf-surface, and the disks were kept at $22 \mathrm{C}$ for 4 days to observe the disease development.

Protoplast isolation and reversion. Mycelium cultured in MS medium for $40 \mathrm{hr}$ was used for protoplast isolation. One gram fresh weight of mycelium was suspended in the enzyme solution and shaked for $2 \mathrm{hr}$ at $35 \mathrm{C}$ as previously described ${ }^{6}$. Reversion of protoplasts was performed according to the procedure of thin-layer agar-plate method $^{4)}$ with some modifications. Protoplasts were suspended in the reversion medium (MS medium supplemented with $0.54 \mathrm{M}$ mannitol and $1 \%$ agarose LGT: Nakarai chemicals, Ltd.) which was maintained at $35 \mathrm{C}$ and solidified to thin layer of $0.1 \mathrm{~mm}$ thickness on hemacytometer glass plate and then incubated at $22 \mathrm{C}$ for overnight.

\section{Results}

\section{Observation of B. cinerea on various MS media in vitro}

Components and their concentrations of which we have established for $B$. cinerea, based on Murashige and Skoog medium ${ }^{5)}$, were shown in Table 1 . The effect of the omission of each component of MS medium on the germination, growth, and sporulation of the fungus was investigated and compared with those in SVg ${ }^{2)}$ (Vogel's mineral salts ${ }^{8)}$ with $2 \%$ sucrose) or PS medium (Table 2). Germination of spores was remarkably decreased in the medium in which $\mathrm{MgSO}_{4}$ or $\mathrm{KH}_{2} \mathrm{PO}_{4}$ was omitted. $\mathrm{MgSO}_{4}$, $\mathrm{NH}_{4} \mathrm{NO}_{3}, \mathrm{KH}_{2} \mathrm{PO}_{4}$ and sucrose were important components for the growth of $B$. cinerea (Table 2, Plate I, Fig. 1). Trisodium citrate, $\mathrm{MnSO}_{4}, \mathrm{ZnSO}_{4}, \mathrm{CaCl}_{2}, \mathrm{Na}_{2} \mathrm{MoO}_{4}$ and vitamin A palmitate promoted the growth of mycelium. The microphotographes of $B$. cinerea after $48 \mathrm{hr}$ incubation were shown in Palte I. In the medium without $\mathrm{MgSO}_{4}$, the spores germinated but did not grow further, just as in the case of distilled water 
Table 1. Components of mineral salt medium for the growth of Botrytis cinerea in vitro

\begin{tabular}{l|c}
\hline \hline Components & Concentration (g/liter distilled water) \\
\hline trisodium citrate & 1.5 \\
$\mathrm{MnSO}_{4} \cdot 4-5 \mathrm{H}_{2} \mathrm{O}$ & 0.5 \\
$\mathrm{MgSO}_{4} \cdot 7 \mathrm{H}_{2} \mathrm{O}$ & 2.0 \\
$\mathrm{ZnSO}_{4} \cdot 7 \mathrm{H}_{2} \mathrm{O}$ & 0.001 \\
$\mathrm{NH}_{4} \mathrm{NO}_{3}$ & 0.7 \\
$\mathrm{KH}_{2} \mathrm{PO}_{4}$ & 4.0 \\
$\mathrm{CaCl}_{2}$ & 0.1 \\
$\mathrm{Na}_{2} \mathrm{MoO}_{4} \cdot 2 \mathrm{H}_{2} \mathrm{O}$ & 0.004 \\
vitamin A palmitate & 0.050 \\
sucrose & 20.0 \\
\hline
\end{tabular}

Table 2. Effect of the omission of each component from mineral salt medium on the growth and sporulation of Botrytis cinerea in vitro

\begin{tabular}{l|c|c|c|c}
\hline $\begin{array}{c}\text { Spores suspended } \\
\text { in }\end{array}$ & $\mathrm{pH}$ & $\begin{array}{c}\text { \% spore } \\
\text { germination }\end{array}$ & $\begin{array}{c}\text { Growth of } \\
\text { mycelium }^{\mathrm{a}}\end{array}$ & $\begin{array}{c}\text { Spore } \\
\text { production }^{\mathrm{b})}\end{array}$ \\
\hline MS medium & & & & \\
complete & 5.25 & 100 & 3,141 & 148 \\
- trisodium citrate & 4.42 & 95.5 & 2,859 & 90 \\
$-\mathrm{MnSO}_{4}$ & 5.33 & 99.3 & 1,636 & 8 \\
$-\mathrm{MgSO}_{4}$ & 5.64 & 65.8 & $0^{\text {c })}$ & 0 \\
$-\mathrm{ZnSO}_{4}$ & 5.26 & 99.6 & 1,394 & 5 \\
$-\mathrm{NH}_{4} \mathrm{NO}_{3}$ & 5.26 & 92.7 & 43 & 0 \\
$-\mathrm{KH}_{2} \mathrm{PO}_{4}$ & 6.46 & 62.3 & $0^{c)}$ & 0 \\
$-\mathrm{CaCl}_{2}$ & 5.28 & 100 & 1,343 & 119 \\
$-\mathrm{Na}_{2} \mathrm{MoO}_{4}$ & 5.25 & 99.7 & 1,691 & 105 \\
- vitamin A palmitate $_{\text {sucrose }}$ & 5.24 & 100 & 2,441 & 143 \\
PS medium & 5.26 & 96.8 & 3 & 0 \\
SVg medium & 5.97 & 99.4 & 4,823 & 113 \\
distilled water & 5.85 & 100 & 1,101 & 185 \\
\hline
\end{tabular}

a) $\mathrm{mg}$ fresh weight $/ 20 \mathrm{ml}$ medium.

b) $\times 10^{6}$ spores/Petri dish.

c) Difficult to collect because of extremely small amount.

(Plate I-3, 8). In the medium omitted $\mathrm{NH}_{4} \mathrm{NO}_{3}$, the spores germinated and formed repeatedly primary appressorium-like structures (Plate I-4). If $\mathrm{KH}_{2} \mathrm{PO}_{4}$ was omitted, the spores formed bold germ tubes and then the growth was stopped (Plate I-5). In the medium omitted sucrose, the spores germinated, but developed thin hyphae (Plate I-6). Many secondary appressoria were formed in the medium without trisodium citrate compared with other media (Plate I-2). The appearance of the fungus grown for 2 weeks on agar-media was shown in Fig. 1. The lack of $\mathrm{MnSO}_{4}$ induced unusual hyphal growth with dark green colour. Sporulation after UV irradiation was extremely poor on the agar-medium which was omitted $\mathrm{MnSO}_{4}$ or $\mathrm{ZnSO}_{4}$ (Table 2, Fig. 1). The spores developed on these chemically defined agar-media germinated over $95 \%$ when they were 


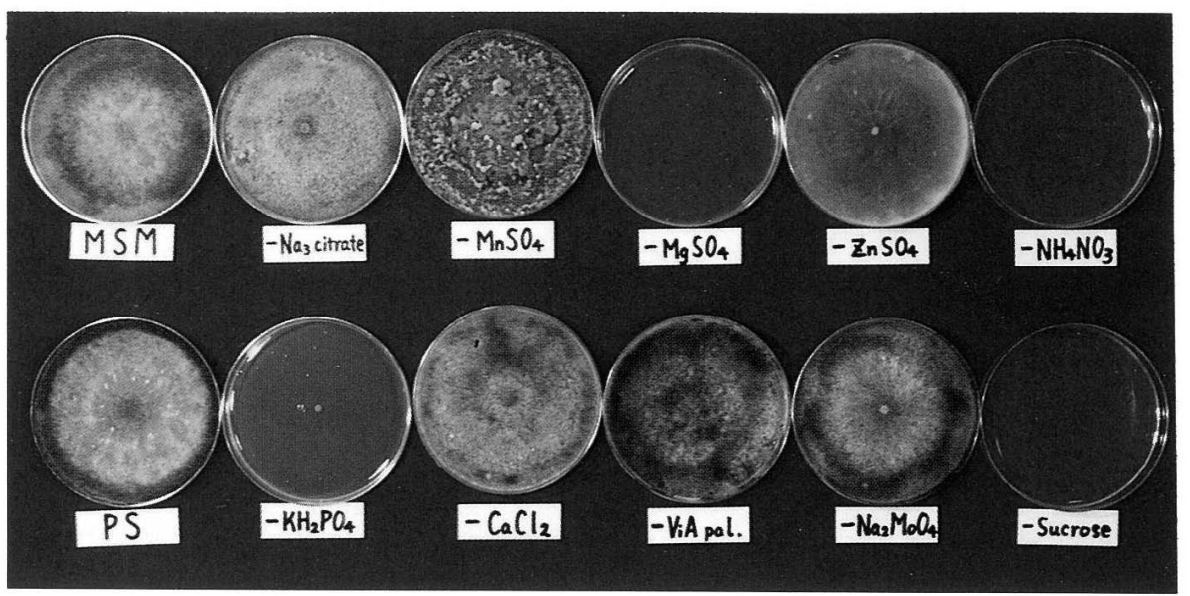

Fig. 1. Effect of the omission of each component in MS agar-medium on the growth of Botrytis cinerea. The fungus was cultured for 2 weeks and photographed.

cultured in PS medium.

\section{Infectivity of spores on cucumber leaf}

The spores stocked at $-80 \mathrm{C}$ were suspended in various test media and inoculated to cucumber leaf disks. The percentage of infection was shown in Table 3. All leaf disks were infected and formed the developing lesions by the spores suspended in PS medium. The spores in MS medium induced similer lesions on about $85 \%$ disks with slow lesion development. $\mathrm{NH}_{4} \mathrm{NO}_{3}, \mathrm{KH}_{2} \mathrm{PO}_{4}$ and sucrose were important for the lesion development, since infectivity was less than $35 \%$ without these components.

Table 3. Infectivity of Botrytis cinerea spores suspended in various mineral salt media to cucumber leaves

\begin{tabular}{c|c}
\hline $\begin{array}{c}\text { Spore suspension } \\
\text { medium }\end{array}$ & $\begin{array}{c}\text { Infectivity } \\
\text { (\% of developing lesions) }\end{array}$ \\
\hline MS medium & \\
complete & 85.7 \\
- trisodium citrate & 88.9 \\
$-\mathrm{MnSO}_{4}$ & 70.0 \\
$-\mathrm{MgSO}_{4}$ & 89.3 \\
$-\mathrm{ZnSO}_{4}$ & 80.0 \\
$-\mathrm{NH}_{4} \mathrm{NO}_{3}$ & 33.3 \\
$-\mathrm{KH}_{2} \mathrm{PO}_{4}$ & 20.0 \\
$-\mathrm{CaCl}_{2}$ & 81.5 \\
$-\mathrm{Na}_{2} \mathrm{MoO}_{4}$ & 92.6 \\
- vitamin $\mathrm{A}$ palmitate & 90.0 \\
- sucrose & 0.0 \\
PS medium & 100 \\
distilled water & 0.0 \\
\hline
\end{tabular}




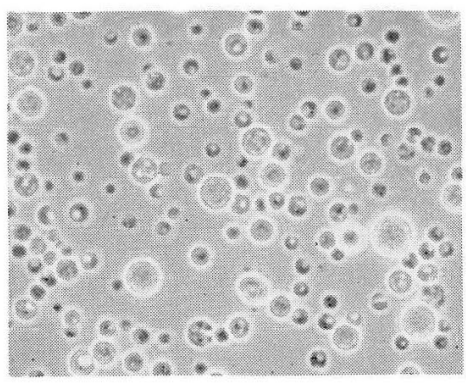

Fig. 2. Numerous protoplasts released from $40 \mathrm{hr}$-old mycelium of Botrytis cinerea cultured in MS meditum

\section{Protoplast isolation}

Protoplasts from the mycelium which was cultured for $40 \mathrm{hr}$ in MS medium was prepared. A large number of protoplasts $\left(4 \times 10^{7} / \mathrm{g}\right.$ f. wt. of mycelium) were isolated and the protoplast preparation was relatively free from the mycelial debris (Fig. 2). Similar results were obtained by repeated experiments. Thirty to $60 \%$ of protoplasts were reverted to mycelium when they were incubated in the reversion medium for overnight.

\section{Discussion}

From the results described above, $\mathrm{MgSO}_{4}, \mathrm{NH}_{4} \mathrm{NO}_{3}, \mathrm{KH}_{2} \mathrm{PO}_{4}$ and sucrose were essential components for the growth of $B$. cinerea. $\mathrm{MnSO}_{4}$ and $\mathrm{ZnSO}_{4}$ promoted sporulation. Trisodium citrate, $\mathrm{CaCl}_{2}, \mathrm{Na}_{2} \mathrm{MoO}_{4}$ and vitamin $\mathrm{A}$ palmitate promoted the fungal growth. Howerer, B. cinerea grew more vigourously in MS medium supplemented with potato extract than in MS medium only (data not shown). Therefore potato extract must contain some other growth factor(s) for B. cinerea. Our results presented here support the findings of Harper and Strange ${ }^{2)}$ who reported the effectiveness of glucose, fructose, raffinose, maltose or sucrose as a carbon source for growth of $B$. cinerea in vitro and the fungus was also versatile in its requirement for a nitrogen source (nitrate, ammonium or amino acids) supporting good growth in vitro and development of aggressive lesions on broad bean leaves.

Shirane and Watanabe ${ }^{7)}$ reported that $B$. cinerea penetrated cucumber leaves not via primary but via secondary appressorium which requires a supply of the exogenous nutrients for its formation. In the MS medium that lacks $\mathrm{MgSO}_{4}, \mathrm{NH}_{4} \mathrm{NO}_{3}$ or $\mathrm{KH}_{2} \mathrm{PO}_{4}$, the spores could not grow to form secondary appressorium in vitro. Thus it was expected that the spores of the fungus suspended in such MS media could not infect cucumber leaf disks. However, the infectivity was not decreased in the medium without $\mathrm{MgSO}_{4}$ or decreased only to 33.3 and $20.0 \%$ in the media without $\mathrm{NH}_{4} \mathrm{NO}_{3}$ and $\mathrm{KH}_{2} \mathrm{PO}_{4}$, respectively. These data indicate that on the surface of cucumber leaves various elements may present; $\mathrm{Mg}$ enough for the fungus to infect and $\mathrm{N}, \mathrm{K}$, and $\mathrm{P}$ also to some extent.

Many investigators demonstrated the infection of $B$. cinerea spores suspended in various media to leaves. For example, Chou and Preece ${ }^{1)}$ reported that the addition of pollen grains to spore suspension induced the development of spreading lesions on 
broad bean leaves. Ko et $a .^{3}{ }^{3}$ could accelerate the lesion formation on cucumber leaves by purine related compounds in the presence of glucose. Recently, Harper and Strange ${ }^{2)}$ used SVg medium for the development of lesions on broad bean leaves. Spores can also infect to cucumber leaves by potato extract ${ }^{7)}$. These experiments and the data we reported here indicate that $B$. cinerea requires appropriate minerals and carbon and nitrogen sources for the growth and infection to host plant leaves.

The MS medium which we reported here would be useful for various studies on $B$. cinerea in vitro and in vivo as well as protoplast manipulations, since the medium contains only chemically defined components.

The authors wish to thank Dr. H. Kunoh, Mie University, Mie, and Dr. Y. Hayashi and Mrs K. Hirooka, Shionogi \& Co., Ltd., Shiga, for their valuable suggestions and helpful cooperations.

\section{Literature cited}

1. Chou, M. C. and Preece, T. F. (1968). Ann. appl, Biol. 62 : 11-22.

2. Harper, A. M. and Strange, R. N. (1981). Physiol. Plant Pathol. $19: 153-167$.

3. Ko, K., Akutsu, K., Kobayashi, Y., Om, Y., Watanabe, T. and Misato, T. (1981). Ann. Phytopath. Soc. Japan $47: 228-233$.

4. Kobayashi, I., Ohkuma, T., Ishizaki, H. and Kunoh, H. (1985). Exp. Mycol. 9 : 161-169.

5. Murashige, T. and Skoog, F. (1962). Physiol. Plant $15: 473-497$.

6. Shirane, N. and Hatta, T. (1986). Ann. Phytopath. Soc. Japan $52: 721-724$.

7. Shirane, N. and Watanabe, Y. (1985). Ibid. $51: 501-505$.

8. Vogel, H. J. (1956). Microb. Genet. Bull. $13: 42-43$.

\section{和 文 摘 要}

白根 昇・八田隆行：灰色かび病菌 (Botrytis cinerea) 培養用無機塩培地

Botrytis cinerea の in vitro 培養に用いるための無機塩培地（MS 培地）を検討した。 MS 培地はクエン 酸三ナトリウム, $\mathrm{MnSO}_{4}, \mathrm{MgSO}_{4}, \mathrm{ZnSO}_{4}, \mathrm{NH}_{4} \mathrm{NO}_{3}, \mathrm{KH}_{2} \mathrm{PO}_{4}, \mathrm{CaCl}_{2}, \mathrm{Na}_{2} \mathrm{MoO}_{4}$, ビタミン $\mathrm{A}$ パルミテー ト及びシュークロースを含み, 本培地上で菌は旺盛任生育し, 多数の胞子を形成した。又, その生育速度はポ テトシュークロース培地に近かった。本培地からいずれの組成を抜いても B. cinerea の生育速度は遅れた。 特に $\mathrm{MgSO}_{4}, \mathrm{NH}_{4} \mathrm{NO}_{3}, \mathrm{KH}_{2} \mathrm{PO}_{4}$, シュークロースのいずれかを抜いた場合 B. cinerea の生育は著しく低下 した。本培地に B. cinerea の分生胞子を懸濁し，キュウリ葉に接種すると約 $85 \%$ の発病率（拡大型病斑）を 示した。乙の培養液から, $\mathrm{NH}_{4} \mathrm{NO}_{3}, \mathrm{KH}_{2} \mathrm{PO}_{4}$, シュークロースのいずれかを抜くと発病率は顕著に低下した。 本培養液で培養した菌系体に酵素処理をすると多量のプロトプラストが分離でき，そのプロトプラストは30〜 60\%の割合で菌系体に復帰する能力を持っていた。

\section{Explanation of plate}

\section{Plate I}

Light microscopy of Botrytis cinerea which was incubated for $48 \mathrm{hr}$ in various MS media (1-6). Compare with PS medium (7) or distilled water (8). Each scale line indicates $10 \mu \mathrm{m}$. 


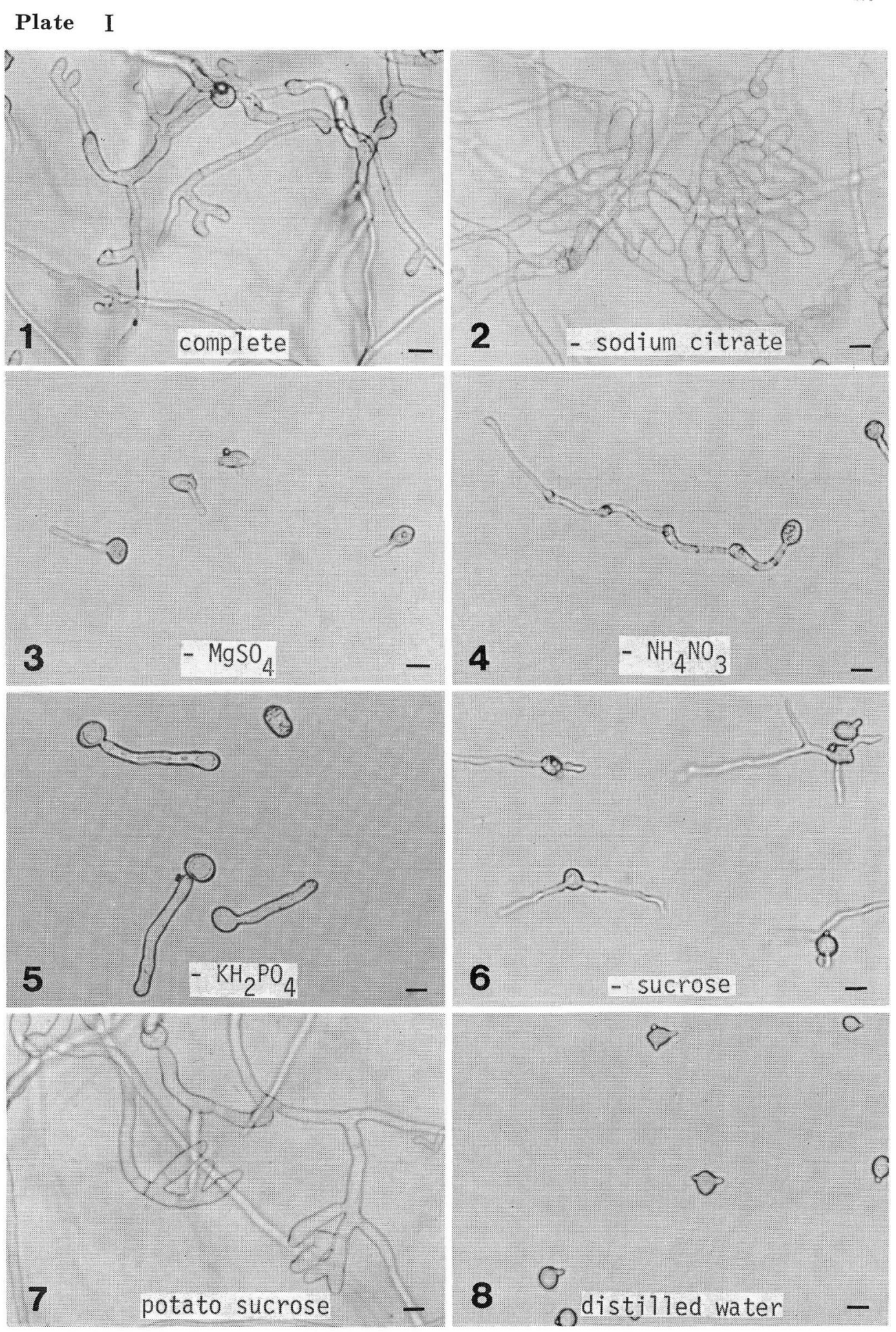

